\title{
Reuse of Woody Biomass Ash Waste in Cementitious Materials
}

\author{
N. Ukrainczyk, ${ }^{a, *}$ N. Vrbos, ${ }^{b}$ and E. A. B. Koenders ${ }^{a}$ \\ anstitute for Construction and Building Materials, Faculty of Civil \\ and Environmental Engineering, Technical University of Darmstadt, \\ Franziska-Braun-Straße 3, 64287 Darmstadt, Germany \\ ${ }^{b}$ Faculty of Chemical Engineering and Technology, \\ University of Zagreb, Marulicev trg 19, 10000 Zagreb, Croatia
}

doi: 10.15255/CABEQ.2015.2231

Original scientific paper Received: May 18, 2015 Accepted: May 31, 2016

There is an increased interest in the reuse of ash waste from biomass combustion, being a sustainable source of energy. This paper investigates the partial replacement of cement and sand in building materials with fly ash waste generated from combustion of woody biomass waste. The results show that the ash widens the particle size distribution of cement and has minerals complementary to portland cement, thus justifying its application as cement replacement, but with a relatively high amount of free $\mathrm{CaO}$ and $\mathrm{MgO}$ that may exert significant expansion. With ash addition, the rate of hydration, strength, and workability decreased. The optimum dosage showed $15 \%$ of ash, replacing $5 \%$ of cement and $3.33 \%$ of sand, which can still produce a structural grade cementitious material with acceptable workability and mechanical properties. The ash exhibits hydraulic and pozzolanic activity that initially increases and subsequently decreases the amount of $\mathrm{Ca}(\mathrm{OH})_{2}$ in the hydrated material.

Key words:

biomass ash, blended cement, hydration, sustainability, waste reuse

\section{Introduction}

Woody and agricultural biomass is among the top biomass-source potentials for energy production in the $\mathrm{EU}$, and is considered a $\mathrm{CO}_{2}$-neutral and renewable source of energy as it releases less $\mathrm{CO}_{2}$ by burning than it absorbs while growing. Therefore, biomass is being used increasingly as a sustainable fuel. The use of energy from these renewable sources $^{1}$ will lead to the annual production of a foreseeable amount of 15.5 million tons of biomass ash in the EU-28 by $2020^{2,3}$. This will double the current annual amount. Presently, most of the biomass ash in Europe is landfilled ${ }^{2,4-6}$, causing financial and material losses, as well as an environmental burden. A possible application for biomass ash could be the replacement of cement and/or sand in cementitious materials $^{2-10}$. The utilization of biomass ash in the construction industry is an environmentally motivated choice. Besides this, it will save costs for ash disposal, decrease energy requirement (for cement clinker production), preserve natural resources (i.e. quarried limestone, sand and natural aggregates that also consume huge amounts of non-renewable and pre-treated natural raw materials), as well as decrease greenhouse gas emissions (by cement clinker substitution). Biomass is a renewable resource for

"Corresponding author: ukrainczyk@wib.tu-darmstadt.de, Tel. +49 (0) 6151-16 22214, Fax: +49 (0) 6151 16-5344 raw materials and energy, so there is no concern over depleting limited supplies.

The primary negative effect of cementitious materials lies in the production of cement clinker. The cement industry produces 5 to $7 \%$ of all global $\mathrm{CO}_{2}$ emissions ${ }^{11,12}$, while annual cement production has recently exceeded 4 billion tons globally, or 220 million tons in the EU. ${ }^{13}$ Some standards prohibit the use of biomass ash in concrete. Technical regulations and standards for coal and co-firing ashes are used as a reference framework for ash producers and building industry customers. An example is the NEN 450-1: Fly ash in concrete ${ }^{14,15}$, which gives a set of requirements to assess the quality of coal fly ash (co-firing percentages up to 50 mass \% of clean wood) for use in concrete. These standards, however, do not apply to pure (non-coal) biomass ash. On the one hand, this leads to rising costs for biomass ash waste managers, which then forces power plant owners to search for new opportunities how to recycle such ash. On the other hand, blending cement with biomass ash could anticipate further improvements in concrete material performance while resulting in a lower environmental impact of cement production, as well as biomass combustion. Therefore, more research on the applicability of biomass fly ash in cementitious materials is desirable. Review of research results from literature has indicated that wood waste ash (WA) has great potential to be effectively utilized as a cement replacement for 
production of blended cement systems and to produce structural grade concretes and mortars of acceptable strength and durability performances?

The physical properties of biomass ash include particle size distribution, shape, density, water absorption/requirement, and influence on rheological behaviour (i.e. workability of final products). Its relevant chemical properties are reactivity (pozzolanic and hydraulic), chemical and mineralogical composition, amount of undesired elements such as unburned carbon and chlorides. Biomass ash ecological properties are related to the amount of heavy metals and their leaching behaviour ${ }^{6,8,16}$. Biomass ash might require attention with regard to the amounts of heavy metals, as they do not meet the established limit concentrations for reuse in agricultural applications as mineral fertilizers. Incorporation of ash into cementitious materials will immobilize the harmful substances in the ash.

Biomass bottom ashes are commonly directly reused as fertilizer on agricultural or forest soils ${ }^{4}$. However, as compared to bottom ash, the reuse of fly ash is more delicate due to higher potential of leaching heavy metals ${ }^{6,8,16}$, so their stabilization in construction and building materials is mostly preferred. A modest level of heavy metals in ashes is generally not a problem. Fly ash might require attention with regard to the amounts of $\mathrm{Cr}, \mathrm{Cd}$ and $\mathrm{Zn}$, while bottom ash generally does not reach levels as present in Portland cement. However, leaching tests should be performed in order to further demonstrate ecotoxic behavior in specific cases and if wood ashes stabilizes in cementitious materials. Besides their reuse in concrete, other possible recycling strategies for the construction and building sector include ${ }^{12}$ : geotechnical works such as soil stabilization and road base construction ${ }^{17,18}$, structure fill/embankments, grouting works (flowable fill), production of alternative binders, e.g., geopolymers ${ }^{19}$, production of synthetic aggregates by cold bonding or sintering, as well as brick ${ }^{21}$ and cement manufacturing ${ }^{22}$ where it can partially replace raw feedstock. Being rich in $\mathrm{Ca}, \mathrm{Si}, \mathrm{Al}$ and $\mathrm{Fe}$ oxides, biomass ash can be used as an alternative raw material, and may be used as a substitute for traditional raw materials needed for clinker production ${ }^{22}$, such as limestone $(90 \%$ of the conventional raw material), shale and clay, which are otherwise mined or purchased ${ }^{23}$. The relatively high $\mathrm{CaO}$ content in biomass ash, as reported in this paper, can replace significantly more limestone in the feed for clinker manufacturing. This will result in lower $\mathrm{CO}_{2}$ emissions, as well as lower energy expenditures due to lower amount of $\mathrm{CaCO}_{3}$ that has to decompose during burning of raw materials for cement manufacturing $\left(60 \%\right.$ of the $\mathrm{CO}_{2}$ originates from the endotherminc decomposition of limestone, the re- maining from fuel $)^{22}$. The relatively small quantities of biomass ash available, when related to the needs of the cement industry, make that only a minor portion of the raw meal in a kiln that can be replaced. Thus, the chemical composition of the minor constituents and undesired elements has minor impact. The most important factors are the high amounts of $\mathrm{CaO}$ and low quantities of undesirable elements such as alkalies, heavy metals, and $\mathrm{Cl}^{-}$embedded in cement. Reported levels of heavy metals in fly and bottom ash from wood ${ }^{22}$ show that only $\mathrm{Cd}$ and $\mathrm{Zn}$ in some fly ash may be of particular relevance.

Combustion in grate (fixed-bed) type furnaces occurs typically above $9500^{\circ} \mathrm{C}$, with several minutes of residence time, thus allowing substantial limestone decomposition in the ash, with a typical conversion ratio higher than $96 \%{ }^{22}$ The $\mathrm{CaO} /$ carbonate amounts of ash depends on the raw feedstock, but also on the ash storage and transportation conditions, as $\mathrm{CaO}$ may spontaneously hydrate and carbonate in moist conditions. In general, biomass ash composition and properties are highly variable and depend on:

1. Type of base-biomass feedstock (e.g. a spectrum of woody or agricultural biomass; different co-combustion combinations with peat and coal),

2. Geographical location (collection and handling process),

3. Combustion technology, e.g. fixed bed (grate), pulverized fuel or fluidized bed boilers.

Ash is further classified by the type of collection from a boiler:

1. Bottom ash collected from the bottom of a combustion chamber,

2. Relatively coarse fly ash collected from cyclones or boilers, and

3. Fine fly ash collected from electrostatic precipitators or bag house filters.

Chowdhury et $a .^{24}$ gave a review on the work done on the reuse of wood ash in concrete from 1991 to 2012. Work on ash obtained from the combustion of forest waste wood and agricultural waste escalated ${ }^{5,7,9,19,25}$. Grée et $a l .{ }^{5}$ indicated that a more contaminated biomass fly ash is obtained by combustion of treated wood waste rather than when forestry or agricultural waste is used as fuel. They investigated various treatment methods, at lab and pilot scale, for lowering the level of contaminants.

Berra et al. ${ }^{6}$ studied the effect of cement type I blends with three different woody ashes: obtained from the combustion of chestnut or poplar virgin wood chips, and the production of scraps of treated wood. This paper reports new results on hydration 
and strength development of general purpose cement (type CEM II) partially replaced with coarse fly ash waste generated by a fixed bed (moving grate) furnace fueled by forest residues and wood waste from the (Croatian) timber industry. Type II cement was chosen for possible synergy with biomass ash (the pozzolan additions already present in this cement type can be activated by alkalies ${ }^{11}$ available in biomass ash), and is the type that is most generally used for building applications and is the most readily available on the market. This is the first study in Croatia on the reuse of biomass ash in cement-based materials.

\section{Biomass ash potential in Croatia}

In Croatia, wood ash is currently mainly generated by sawmills, the wood products industry and pulp mills, and by burning wood wastes from forests and the wood industry, such as bark, twigs, knots, chips, etc. Croatia has a very large wood industry and biomass fuel potential, as $48 \%$ of its territory are forests. The timber manufacturing and power generation industry is increasingly shifting towards the use of biomass waste from timber and forest processing for heat and electrical energy co-production. Currently, there are a small number (mainly grate furnace types) heat and power co-generation biomass plants, part of the timber industry in Croatia (namely: Strizivojna Hrast d.o.o., Vinkovci; Univerzal d.o.o., Varaždin; Lika Energo Eko d.o.o., Udbina; Pelet Grupa d.o.o., Novska; Vrbovsko eko energija, Vrbovsko; Spin Valis Int., Požega). They produce in total about 3500 tons of woody ash per year, according to our rough estimation. The official Croatian target is to increase biomass-derived electricity (from 7MWe available in 2013) to 140 MWe until 2020, and 420 MWe by $2030 .{ }^{26}$ This will result in a tremendous increase in total ash waste of up to 42,000 tons by 2020 , and 126,000 tons per year by 2030 . When also considering the thermal energy plants that produce only heat without electricity, there is an additional amount of 1,500 tons of ash per year, and this number isexpected to increase significantly. With this increasing demand for biomass fuel-based energy production, ash waste volumes will increase and major challenges will arise relating to the efficient management of the by-products. This paper investigates the application of woody biomass ash as a cement and sand replacement in cement-based materials.

\section{Materials and methods}

The materials used for preparation of cement paste and mortar specimens were as follows:
1. Commercial Portland cement (Nexe Specijal, produced by Nexe Nasice cement d.d., Croatia) CEM II/A-M (S-V) $42,5 \mathrm{~N}$ that contains min. $80 \%$ clinker, up to $20 \%$ combination of ground granulated blast furnace slag, and coal-derived class F fly ash, natural gypsum $\left(2.6 \% \mathrm{SO}_{3}\right)$, and $0.006 \% \mathrm{Cl}$. The initial setting time is $200 \mathrm{~min}$. This blended cement was chosen for possible synergy with biomass ash (activation of the pozzolans in cement by the alkalies in biomass ash), and as a type for general-purpose applications, and the most readily available on the market.

2. EN 196-1 CEN Standard siliceous sand.

3. Biomass fly ash produced by 1 MWe cogeneration plant Lika Eko-Energo d.o.o., Udbina, Croatia: with a fixed bed (moving grate) furnace fueled by forest residues and wood waste from the timber industry in Croatia. Properties of the ash are characterized in the next section.

4. Deionised water.

For investigating cement paste hydration and mortar properties, samples were prepared from a mix of cement, woody ash, water, and standard sand, according to the standard ratios given in Table 1. The standard procedures for cement paste and mortar preparation in the laboratory were followed. The experimental plan with mix compositions and sample notations is given in Table 1. Mortar mixtures were designated $\mathrm{M}$, while paste mixtures $\mathrm{P}$, followed by two numbers: the first number represents the percentage of cement replacement by fly ash, and the second number (only for mortar) shows the fly ash amount relative to the amount of cement in the reference mixture. For example, M5W15 nominal mortar mixture has a woody ash amount of $15 \%$ cement in the reference mixture, while the cement and sand replacement level is $5 \%$ cement and $3.3 \%$ sand (which corresponds to $10 \%$ cement, as the sand to cement mass ratio is 3). Fresh mortar samples were tested for workability, while aged samples were tested for compressive and flexural strength (at 1, 3, and 28 days, and accelerated further ageing by heating the 28-day specimens in water bath at $100{ }^{\circ} \mathrm{C}$ for $3 \mathrm{~h}$ ). Mortars were mixed at a constant water to cement ratio $(\mathrm{w} / \mathrm{c}=0.5)$ and workability was tested for all mixtures. Compression and flexural strength tests of hardened mortars were performed according to EN 1015-11. Paste samples were tested using calorimetry, XRD, TG, and various soundness measurements. Cement paste samples were prepared with a fixed $\mathrm{w} / \mathrm{c}=0.5$ for the calorimetry, XRD, and TG tests. For the cement paste test series, the water requirement and volume stability were measured for a fixed paste workability (at flow table value $K=150 \pm 5 \mathrm{~mm}$ ), Table 1 . 
Table 1 - Experimental plan for mortar $(M)$ and paste $(P)$ mix compositions, sample notation and obtained mortar workability, as well as water requirement for the fixed paste workability (at flow table value $K=150 \pm 5 \mathrm{~mm}$ )

\begin{tabular}{|c|c|c|c|c|c|c|}
\hline Sample name & $\begin{array}{l}\text { Sand:cement mass } \\
\text { ratio }\end{array}$ & $\begin{array}{l}\text { Sand replacement } \\
\text { with WA, \% }\end{array}$ & $\begin{array}{c}\text { Cement replacement } \\
\text { with WA, \% }\end{array}$ & \multicolumn{2}{|c|}{ Water:cement mass ratio } & $\begin{array}{l}\text { Workability, flow } \\
\text { table, } \mathrm{mm}\end{array}$ \\
\hline M & \multirow{5}{*}{3} & 0 & 0 & \multirow{5}{*}{\multicolumn{2}{|c|}{0.5}} & 160 \\
\hline M10 & & 0 & 10 & & & 130 \\
\hline M15 & & 0 & 15 & & & 115 \\
\hline M20 & & 0 & 20 & & & 105 \\
\hline M5W15 & & 3.33 & 5 & & & 145 \\
\hline $\mathrm{P}$ & \multirow{6}{*}{0} & \multirow{6}{*}{-} & 0 & \multirow{6}{*}{$0.5 !$} & $0.300^{*}$ & \multirow{6}{*}{$(150 \pm 5)^{\#}$} \\
\hline $\mathrm{P} 10$ & & & 10 & & $0.308^{\#}$ & \\
\hline P15 & & & 15 & & $0.316^{*}$ & \\
\hline $\mathrm{P} 20$ & & & 20 & & $0.324^{*}$ & \\
\hline P30 & & & 30 & & $0.339^{\#}$ & \\
\hline WA & & & 100 & & $0.310^{\#, *}$ & \\
\hline
\end{tabular}

' calorimetric, XRD and TG tests;

\# volume stability (soundness) and water requirement tests for the fixed workability;

* flow table test not applicable

Table 2 - Chemical composition of wood ash (XRF pressed tablets, mas. \%)

\begin{tabular}{c|c|c|c|c|c|c|c|c|c}
\hline $\mathrm{SiO}_{2}$ & $\mathrm{CaO}$ & $\mathrm{K}_{2} \mathrm{O}$ & $\mathrm{P}_{2} \mathrm{O}_{5}$ & $\mathrm{Al}_{2} \mathrm{O}_{3}$ & $\mathrm{MgO}$ & $\mathrm{Fe}_{2} \mathrm{O}_{3}$ & $\mathrm{SO}_{3}$ & $\mathrm{Na}_{2} \mathrm{O}$ & $\mathrm{TiO}_{2}$ \\
\hline 15.0 & 55.5 & 10.7 & 0.90 & 2.59 & 2.66 & 3.98 & 1.4 & 0.64 & 0.51 \\
\hline $\mathrm{Cr}_{2} \mathrm{O}_{3}$ & $\mathrm{ZnO}$ & $\mathrm{MnO}$ & $\mathrm{BaO}$ & $\mathrm{SrO}$ & $\mathrm{CuO}$ & $\mathrm{SnO}_{2}$ & $\mathrm{Rb}_{2} \mathrm{O}$ & $\mathrm{ZrO}_{2}$ & $\mathrm{Y}_{2} \mathrm{O}_{3}$ \\
\hline 0.037 & 0.045 & 0.63 & 0.127 & 0.073 & 0.032 & 0.053 & 0.056 & 0.100 & 0.010 \\
\hline
\end{tabular}

With the soundness tests, the ability to resist a volumetric expansion was obtained by Pat (EN 4592) and Le Chatelier (EN 196-3) tests, where the cement pastes were cured for $24 \mathrm{~h}$ at room temperature, and boiled for $3 \mathrm{~h}$, so that any tendency to expand was accelerated and detectable. The cement paste cake was visually inspected for cracks by applying the Pat test. Le Chatelier tests (cylinders $H$ $=D=30 \mathrm{~mm}$ ), were applied to obtain the expansion value as a difference $\left(d_{2}-d_{1}\right)$ between the distance of the Le Chatelier needle tips before boiling $\left(d_{1}\right)$, and after boiling $\left(d_{2}\right)$.

The heat of hydration evolution was measured by means of a self-adopted laboratory differential calorimeter $^{27}$ capable of giving information on the heat evolution of cement pastes from the moment of water injection in the sample holder. The differential calorimeter consisted of two cells - sample cell and reference cell. These two cells were thermally isolated by silicon rubber and connected by a thermopile consisting of 30 thermocouples. The voltage, proportional to the heat flux, was stored every 10 seconds by a data logger PICO Logger TC-08 (Pico Technology Ltd., UK: 20 bits, 8 channels, voltage resolution $1 \mu \mathrm{V}$ ). To assure a good wetting of the cement, a hole through the cement sample in the sample holder was created with a glass stick (2 $\mathrm{mm}$ thick), and a relatively high $\mathrm{w} / \mathrm{c}$ ratio $(0.5)$ was used. Ten grams of powder (homogenized mixtures of cement and biomass ash), and 5 grams of water was left to reach thermal equilibrium (overnight) in an ultra-thermostat before the thermostated water was injected (by syringe) into the sample holder to start the hydration.

The chemical composition of the woody ash was determined on pressed tablets made of grinded samples, and using the X-ray fluorescence (XRF) analyzer by Philips. The amount of unburned carbon was determined according to EN15104. The woody ash was analyzed for water-soluble and total chlorides (dissolved in $\mathrm{HNO}_{3}$ ) according to AFFREM test procedures ${ }^{28}$. Particle size distribution of cement and fly ash was obtained by laser diffraction using the Shimadzu SALD 3101. Scanning electron micrographs (SEM) were obtained using a SEM-TESCAN VEGA TS5236LS scanning microscope. Samples were placed over a graphite strip and coated with gold. Specific surface area of cement and fly ash was measured by a BET method using Micromeritics ASAP 2000 for adsorption-desorption of $\mathrm{N}_{2}$ at $77 \mathrm{~K}$. The composition of crystalline reactants and products during hydration was investigated using powder X-ray diffraction (XRD). Shimadzu diffractometer XRD-6000 with $\mathrm{CuK} \alpha_{1,2}$ radiation was used (the scan step was $0.02^{\circ}$ with an integration time per step of $0.6 \mathrm{~s})$. The hydration was stopped and free (unreacted) water removed by grinding the sample with addition of acetone (2-propanone) in agate mortar (exposure to $\mathrm{CO}_{2}$ was min- 
imized). Thermo-gravimetric analysis (TGA) was performed with a NETZSCH STA409 apparatus at a heating rate of $10 \mathrm{~K} \mathrm{~min}^{-1}$ over a temperature range of $40-1100{ }^{\circ} \mathrm{C}$ with $\mathrm{N}_{2}$ flow of $30 \mathrm{~cm}^{3} \mathrm{~min}^{-1}$. The platinum sample holder (crucible) contained samples of around $50 \mathrm{mg}$.

The workability (fluidity) of the fresh mortar was tested using the standard flow table test according to EN 1015-3. The test procedure involved placing the mold $(60 \mathrm{~mm}$ height, internal diameter: base $100 \mathrm{~mm}$ - top $70 \mathrm{~mm}$ ) in the center of the flow table. A period of $15 \mathrm{~s}$ was allowed to elapse before the mold was removed, and the table jolted 15 times at a rate of one jolt per second. The mean diameter of the spread mortar (or paste) was recorded.

\section{Results and discussion}

\section{Biomass ash characterization}

Particle size distribution of fly ash and cement is presented in Fig. 1. The results show that the ash was widening the particle size distribution of cement as it comprised particles smaller than $1 \mu \mathrm{m}$ and larger than $100 \mu \mathrm{m}$. This suggests great potential of the biomass ash which may improve the packing density of blends. This observation differs from literature ${ }^{5,7,9,19,24,25}$ where the focus was mainly on the fine particle range (below $90 \mu \mathrm{m}$ ) of wood fly ash. Moreover, only a few papers deal with the reuse of woody fly ash as a sand replacement ${ }^{9}$.

SEM-SE micrographs (Fig. 2) show the size and morphological diversity of woody coarse fly ash, ranging from spherically fused to irregularly shaped and porous particles. It was observed that particle size distribution, shape, and texture of fly ash particles affected the rheological properties (workability) of the samples. Spherical particles together with the particle size distribution increased the overall packing density of the mixture and promoted workability of the cement based materials in general. On the other hand, irregularly shaped and porous fly ash particles tended to absorb water and decrease the workability of mortar. From the decreased workability with addition of fly ash (Table 1 ), it can be concluded that the negative effect of porous particles prevails over the particles being spherically shaped.

The specific surface area obtained by BET for cement $\left(1.66 \mathrm{~m}^{2} \mathrm{~g}^{-1}\right)$ is higher than that of woody fly ash $\left(0.58 \mathrm{~m}^{2} \mathrm{~g}^{-1}\right)$. This is in agreement with results obtained from the particle size distribution (Fig. 1), where 50 vol. \% of the fly ash particles were larger than $146 \mu \mathrm{m}$, while for cement this was $24.5 \mu \mathrm{m}$ with a maximum particle size of $40 \mu \mathrm{m}$.

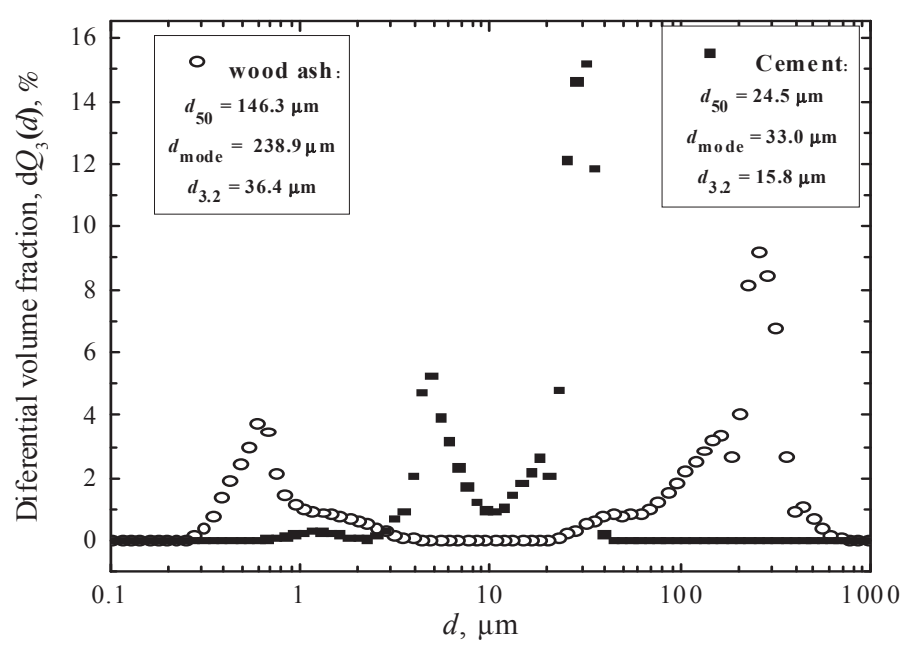

Fig. 1 - Particle (volume) size distribution of woody ash and cement
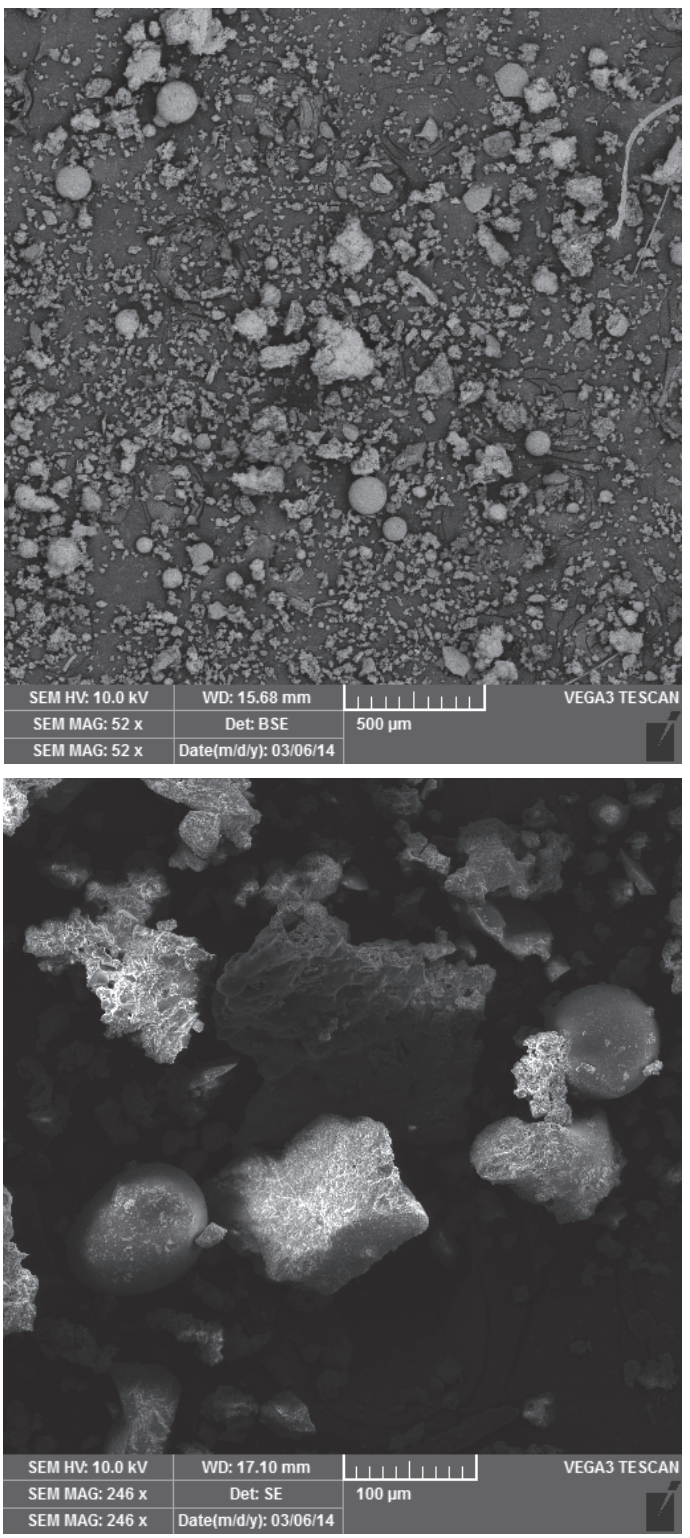

Fig. 2 - SEM-SE micrographs showing the size and morphological diversity of woody coarse fly ash 
The chemical composition of wood ash (Table 2) showed a relatively high level of $\mathrm{CaO}, \mathrm{MgO}$ and $\mathrm{K}_{2} \mathrm{O}$. These levels were higher than reported in literature ${ }^{2,5-7,16}$. Alkali oxides $\left(\mathrm{Na}_{2} \mathrm{O}+\mathrm{K}_{2} \mathrm{O}\right)$ may be considered acceptable in amounts up to $2 \%$ in cement, and up to $5 \%$ in fly ash (EN 450-1). Alkali content in woody ash was around $10 \%$, which contributed with $1.5 \%$ for $15 \%$ replacement of the cement. This was then $2.5 \%$ of absolute $(1.5 \%$ from ash $+1 \%$ from cement, which was also above the upper limit value for blended cements). However, higher additions of ash were investigated here as well, because the alkalies in biomass ash were expected to activate the pozzolans in the blended cement, and subsequently combine with pozzolanic calcium-silicate hydrates in the long term. Beside alkalies, the ash also did not meet the following EN 450-1 requirements: reactive $\mathrm{CaO}$ less than $10 \%$, reactive $\mathrm{SiO}_{2}$ greater than $25 \%, \mathrm{MgO}$ less than 4 $\%$, the sum of $\left(\mathrm{SiO}_{2}+\mathrm{Al}_{2} \mathrm{O}_{3}+\mathrm{Fe}_{2} \mathrm{O}_{3}\right)$ greater than $70 \%$.

The ash might require attention regarding the amounts of $\mathrm{Cr}, \mathrm{Cd}$ and $\mathrm{Zn}$. Leaching tests should be performed in order to further demonstrate ecotoxic behaviour of the stabilization in cementitious materials.

The chloride content of the ash was below the $0.1 \%$ limit: $0.037 \%$ for water-soluble, and 0.054 $\%$ for acid-soluble. The amount of unburned carbon (EN15104) was $1.87 \%$.

Qualitative analysis of fly ash X-ray diffraction data (Fig. 3) determined the main mineral phases of the sample as being lime (free $\mathrm{CaO}$ ), $\mathrm{MgO}$, larnite $\left(2 \mathrm{CaO} \cdot \mathrm{SiO}_{2}\right)$, calcium carbonate $\left(\mathrm{CaCO}_{3}\right)$, quartz $\left(\mathrm{SiO}_{2}\right)$, Brownmillerite $\left(4 \mathrm{CaO}_{4} \cdot \mathrm{Al}_{2} \mathrm{Fe}_{2} \mathrm{O}_{6}\right)$, and calcium aluminosilicate $\left(2 \mathrm{CaO} \cdot \mathrm{Al}_{2} \mathrm{O}_{3} \cdot \mathrm{SiO}_{2}\right)$. Between $25-35^{\circ} 2 \theta$, the larnite $\left(\mathrm{Ca}_{2} \mathrm{SiO}_{4}\right)$ phase exhib-

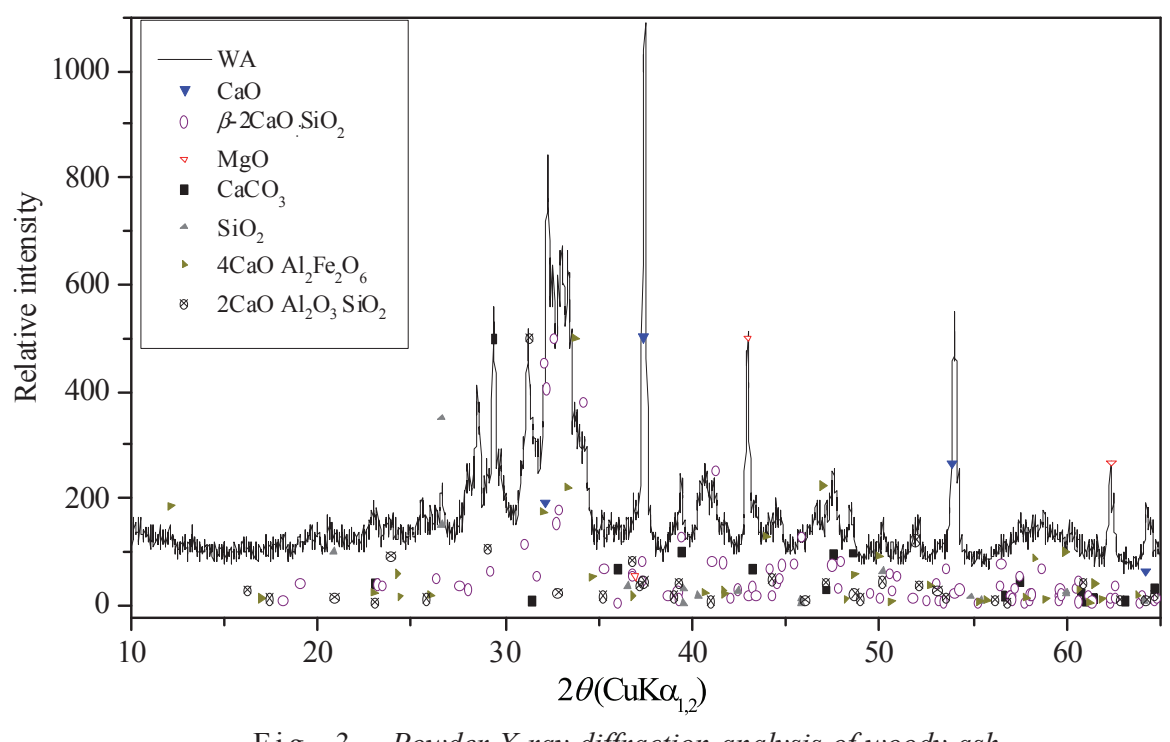

Fig. 3 - Powder X-ray diffraction analysis of woody ash its a number of diffraction peaks of greatest intensity - this is one of the main minerals in Portland cement. The results of this mineral analysis confirm the hydraulic potential and application of this fly ash for the purpose of replacing a part of cement in the composite. Mineralogical analysis also indicates amorphous material present in the wood ash. However, the mineralogical composition differs from the results previously found in literature $\mathrm{e}^{2,5-7,16}$, where free $\mathrm{CaO}$, free $\mathrm{MgO}$, larnite, and $4 \mathrm{CaO}_{4} \cdot \mathrm{Al}_{2} \mathrm{Fe}_{2} \mathrm{O}_{6}$ were absent or present in significantly lower amounts. Small amounts $(\sim$ few $\%)$ of $\mathrm{CaO}$ (as well as few \% of $\mathrm{MgO}$ ) may be acceptable in PC. However, excessive amounts must be avoided as this may cause expansion, strength loss, cracking and disintegration of the hydrated material.

\section{Cement paste hydration}

\section{Soundness}

The results of volume stability (soundness) tests (Table 3 ) show that the addition of more than $15 \%$ of ash causes unacceptable expansions (the limit value is $10 \mathrm{~mm}$ ), which increases very rapidly with further ash dosage. The maximum soundness level reported in literature ${ }^{6,724}$ was for a $30 \%$ replacement, which was still much lower than the maximum allowable soundness limit. Moreover, it is interesting that the $10 \%$ addition shows lower expansion than plain cement paste (confirmed by three mixing repetitions of the test, with a total of 9 replicates). For hydration of plain ash, the expansion of $70 \mathrm{~mm}$ was observed already after $24 \mathrm{~h}$ of curing, even without boiling. These expansions are due to a delayed hydration of free (dead-burned) $\mathrm{CaO}$ to $\mathrm{Ca}(\mathrm{OH})_{2}$, which takes place topochemically, meaning that water diffused towards $\mathrm{CaO}$, and $\mathrm{Ca}(\mathrm{OH})_{2}$ had formed in its place. Most of the oxide converted to hydroxide only when the cement had been largely hydrated, and a firm microstructure had already been formed. Thus, a delayed increase in volume generated internal stresses within the paste. The hydration of free (dead-burned) $\mathrm{MgO}$ was much slower than free $\mathrm{CaO}$, and thus any problems associated with its presence were apparent only after years of service. The effect of this detrimental expansion could be minimized/avoided by washing (pre-hydration and carbonation), and mechanical (grinding) pre-treatments. However, this is out of the scope of the current paper, but should be investigated 
Table 3 - Results of volume stability (soundness) test

\begin{tabular}{c|c|c}
\hline Sample & Le Chatelier, mm & Pat test \\
\hline P & 1.0 & No cracks \\
P10 & 0.5 & No cracks \\
P15 & 1.5 & No cracks \\
P20 & 20 & Disintegrates \\
P30 & 65 & Disintegrates \\
WA & $70 !$ & Disintegrates \\
\hline
\end{tabular}

without boiling

in future research. On the other hand, the expansion potential of the ash could be advantageously used to mitigate autogenous shrinkage problems of high-performance cement-based materials made with very low water to binder ratios. Autogenous shrinkage induced by self-desiccation due to chemical shrinkage ${ }^{29}$ can be compensated by expansive additives ${ }^{30}$. When restrained, the shrinkage-induced internal stresses may cause cracks, which impair the durability of the cement-based materials. The potential of woody ash as an expansive additive (due to high free $\mathrm{CaO}$ and $\mathrm{MgO}$ content) represents a new research line worth investigating.

\section{Calorimetry}

The results of calorimetric measurements performed on the prepared cement composites (Fig. 4) show a change in sample temperature during hydration. The temperature rise occured due to an exothermic hydration reaction of cement and woody ash, which released a significant amount of heat. The duration of induction time (dormant stage) during which the material was still plastic and workable, occured before massive precipitation of hydrates. The induction time was prolonged by the addition of woody ash (Fig. 4). The analysis of calorimetric results shows that the end of the induction period occured after 2, 5, 6, and 7 hours, respectively, for samples with an increased content of woody ash.

According to the early age temperature measurements, it is obvious that pure woody ash hydration was different from cement/woody ash hydration. Pure woody ash did not have an expressed induction period, but the reactions of dissolution and precipitation overlapped. The effect of woody ash on the beginning of cement hydration is shown in Fig. 4. It can be observed that pure cement achieved the highest and narrowest maximum in the shortest time, i.e. the reaction quickly moved into the induction period. Contrarily, woody ash had an elongated first hydration maximum, and had no visibly expressed induction period, but the reactions of

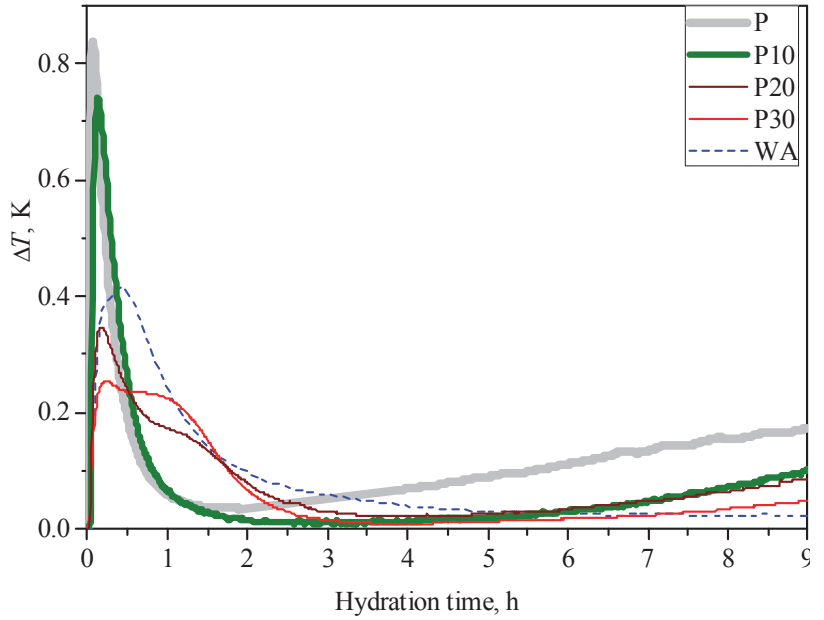

Fig. 4 - Early age (first 4 hours) temperature rise of paste samples during micro-calorimetric measurements (effect of woody ash (WA) addition)

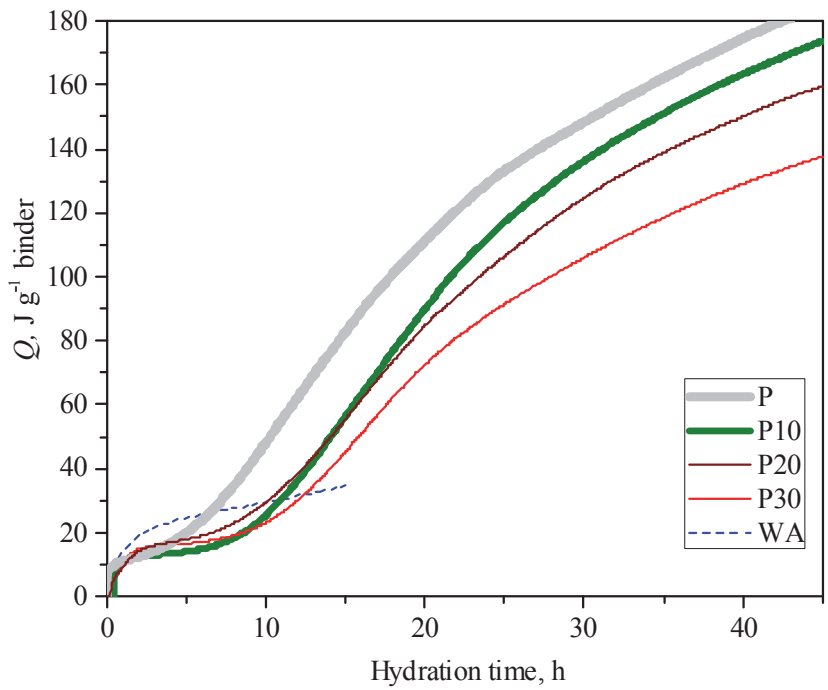

Fig. 5 - Heat of hydration evolution for paste samples (effect of WA addition)

dissolution and precipitation overlapped. With addition of woody ash, two initial maximums were expressed. The first, the earliest one (at $0.1 \mathrm{~h}$ ) was reduced, while the second (at $1 \mathrm{~h}$ ) was increased (Fig. 4). In the case of cement and cement/woody ash materials, the initial setting time corresponds approximately to the end of the induction period. After ending of the induction period, heat generation increased rapidly due to the massive precipitation of the hydration products. Cumulative heat of hydration evolution for paste samples with effect of WA addition is shown in Fig. 5. The addition of ash showed a retardation of setting time, a lower main maximum of the reaction rate (inflection point in Fig. 5) reached at later times (11, 15, 16, and $17 \mathrm{~h})$, while demonstrating the extensive retardation of cement hydration by ash. Due to the retardation and deactivation (dilution) of the hydration reactions, 
the final heat evolved after $45 \mathrm{~h}$ significantly decreased with $(10,20$, and $30 \%)$ ash addition: by -6 $\%,-13 \%$ and $-25 \%$ of the reference cement, respectively. The hydration of ash alone, not yet reported in literature, exhibited a significant hydration heat development, attributed to hydration reactions of $\mathrm{CaO}$ and $\mathrm{MgO}$, as well as larnite and aluminate phases.

\section{Thermogravimetry}

The portlandite content was obtained from TG curves by employing a tangential approach ${ }^{31}$. The result was related to the reactive binder mass obtained after firing at $1100{ }^{\circ} \mathrm{C}$, and considering that $27 \%$ of the ash was reactive. This percentage was taken from ash particle size distribution, where 27 mas. \% were smaller than $80 \mu \mathrm{m}$, while larger particles only act as inert sand. Fig. 6 shows the development of portlandite $\left(\mathrm{Ca}(\mathrm{OH})_{2}\right)$ as a function of time. Five curves were plotted, corresponding to the hydration of reference, blended pastes with 10, 20, and $30 \%$ ash, and plain ash. With hydration of the reference cement paste, the produced quantity of $\mathrm{Ca}(\mathrm{OH})_{2}$ increased continuously with hydration time. During the plain ash hydration, however, the $\mathrm{Ca}(\mathrm{OH})_{2}$ quantity reached a maximum at 3 days, which was lower than the quantity reached by the reference cement paste hydration, and drastically decreased with further hydration (note that the results are normalized per $100 \mathrm{~g}$ of binder, where only 27 mas. \% of ash was considered as reactive). To convert to $\mathrm{g} / 100 \mathrm{~g}$ of ash, the results in Fig. 6 should be multiplied by a factor of 0.27 . The development of $\mathrm{Ca}(\mathrm{OH})_{2}$ during hydration of plain woody ash alone has not yet been investigated in literature. Moreover, a new trend for the development of $\mathrm{Ca}(\mathrm{OH})_{2}$ over hydration time is reported here. The

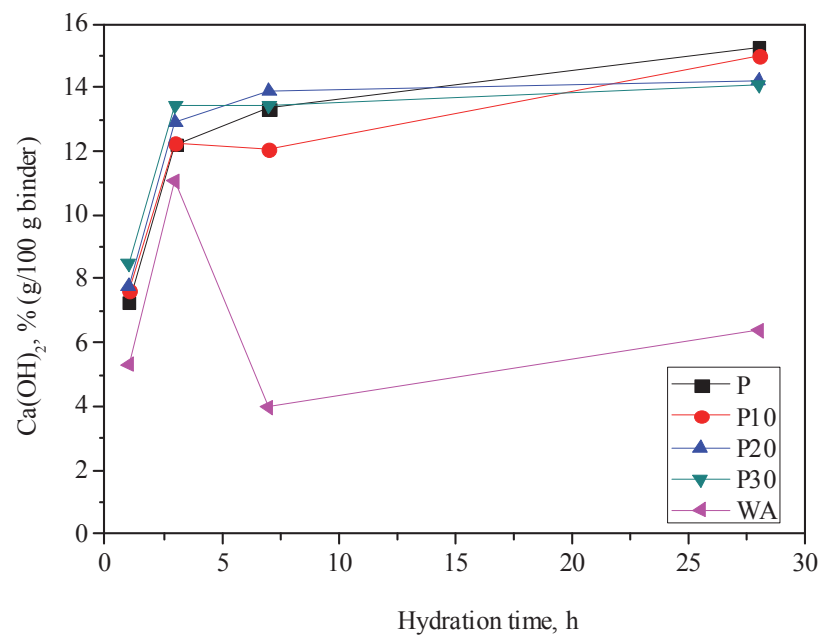

Fig. 6 - Evolution of $\mathrm{Ca}(\mathrm{OH})$, during hydration obtained from TG analysis: Only 27 mass \% of the woody ash (WA) was considered as a binder, corresponding to the mass of particles below $80 \mu \mathrm{m}$ observed peak in $\mathrm{Ca}(\mathrm{OH})_{2}$ formation during ash hydration was consistent with its rapid initial hydration of high $\mathrm{CaO}$ bearing phases (primarily $\mathrm{CaO}$ and $\mathrm{C}_{2} \mathrm{~S}$ ), and subsequent activation of pozzolanic reaction of the ash with the produced $\mathrm{Ca}(\mathrm{OH})_{2}$. $\mathrm{Ca}(\mathrm{OH})_{2}$ was consumed and used for the formation of calcium-aluminate hydration products $(3 \mathrm{CaO}$. $\left.\mathrm{Al}_{2} \mathrm{O}_{3} \cdot \mathrm{Ca}(\mathrm{OH})_{2} \cdot \mathrm{xH}_{2} \mathrm{O}\right)$ but also possibly pozzolanic calcium-silicate hydrates (with a lower $\mathrm{Ca} / \mathrm{Si}$ ratio $)^{11}$. The blended system exhibited a superimposed/combined effect of the hydration results from the individual components: cement and ash. The 10 $\%$-blend curve (P10) also exhibited the drop of $\mathrm{Ca}(\mathrm{OH})_{2}$ from day 3 to 7 , as observed for plain ash. In comparison to the hydration of the reference cement, initially (day 1 and 3) more $\mathrm{Ca}(\mathrm{OH})_{2}$ was produced for higher ash blends due to high hydraulic properties of the ash (relatively high content of the reactive $\mathrm{CaO}$ phases), but later $\mathrm{Ca}(\mathrm{OH})_{2}$, was consumed more for higher ash contents due to increased pozzolanic reaction.

\section{$X R D$}

Figs. 7 and 8 show diffractograms of paste samples hydrated for 1 and 28 days, respectively. Each figure shows the effect of ash addition. Beside clinker phases, also the following hydration products were identified: $\mathrm{Ca}(\mathrm{OH})_{2}$, Ettringite $(3 \mathrm{CaO}$. $\mathrm{Al}_{2} \mathrm{O}_{3} \cdot 3 \mathrm{CaSO}_{4} \cdot 32 \mathrm{H}_{2} \mathrm{O}$ ), $\mathrm{AFm}$ (anionic clay) phases, namely $3 \mathrm{CaO} \cdot \mathrm{Al}_{2} \mathrm{O}_{3} \cdot \mathrm{Ca}(\mathrm{OH})_{2} \cdot \mathrm{xH}_{2} \mathrm{O}$ and Monosulphate aluminate $\left(3 \mathrm{CaO} \cdot \mathrm{Al}_{2} \mathrm{O}_{3} \cdot \mathrm{CaSO}_{4}^{2}\right.$. $13 \mathrm{H}_{2} \mathrm{O}$ ). With elapse of hydration time, there was a relative increase in diffraction peaks of the hydration products, predominantly $\mathrm{Ca}(\mathrm{OH})_{2}, \mathrm{CaCO}_{3}$, and calcium-silicate hydrate (CSH), as well as Ettringite and AFm phases. Unfortunately, the overlapping of $\mathrm{CaCO}_{3}$ and amorphous $\mathrm{CSH}$ diffraction lines (at around 29.3 degrees two theta) made their separation and semi-quantitative analysis impossible. Hydration of ash alone showed the development of $3 \mathrm{CaO} \cdot \mathrm{Al}_{2} \mathrm{O}_{3} \cdot \mathrm{Ca}(\mathrm{OH})_{2} \cdot \mathrm{xH}_{2} \mathrm{O}, \mathrm{CaCO}_{3}$, and/or $\mathrm{CSH}$. The main effect of ash on hydration visible by semi-quantitative $\mathrm{XRD}$ analysis was in production of the $3 \mathrm{CaO} \cdot \mathrm{Al}_{2} \mathrm{O}_{3} \cdot \mathrm{Ca}(\mathrm{OH})_{2} \cdot \mathrm{xH}_{2} \mathrm{O}$ phase, which increased with ash addition (and with hydration time). This demonstrates that ash had a reactive form of aluminate phases, namely $4 \mathrm{CaO}_{4} \cdot \mathrm{Al}_{2} \mathrm{Fe}_{2} \mathrm{O}_{6}$ and $2 \mathrm{CaO} \cdot \mathrm{Al}_{2} \mathrm{O}_{3} \cdot \mathrm{SiO}_{2}$ (Fig. 3), which contributed to a pozzolanic reaction that reduced the content of the most soluble $\mathrm{Ca}(\mathrm{OH})_{2}$. Moreover, very interestingly and not yet reported in literature, was the hydration of ash alone, showing formation of a very stable (desirable and durable) hydration product stratlingite $\left(\mathrm{Ca}_{2} \mathrm{Al}_{2}\left(\mathrm{SiO}_{2}\right)(\mathrm{OH})_{10} 2.5\left(\mathrm{H}_{2} \mathrm{O}\right)\right)$, the origin of which may be attributed to a combined hydration of $2 \mathrm{CaO} \cdot \mathrm{SiO}_{2}, 4 \mathrm{CaO} \cdot \mathrm{Al}_{2} \mathrm{Fe}_{2} \mathrm{O}_{6}$ and $2 \mathrm{CaO}$ $\cdot \mathrm{Al}_{2} \mathrm{O}_{3} \cdot \mathrm{SiO}_{2} \cdot{ }^{32}$ 


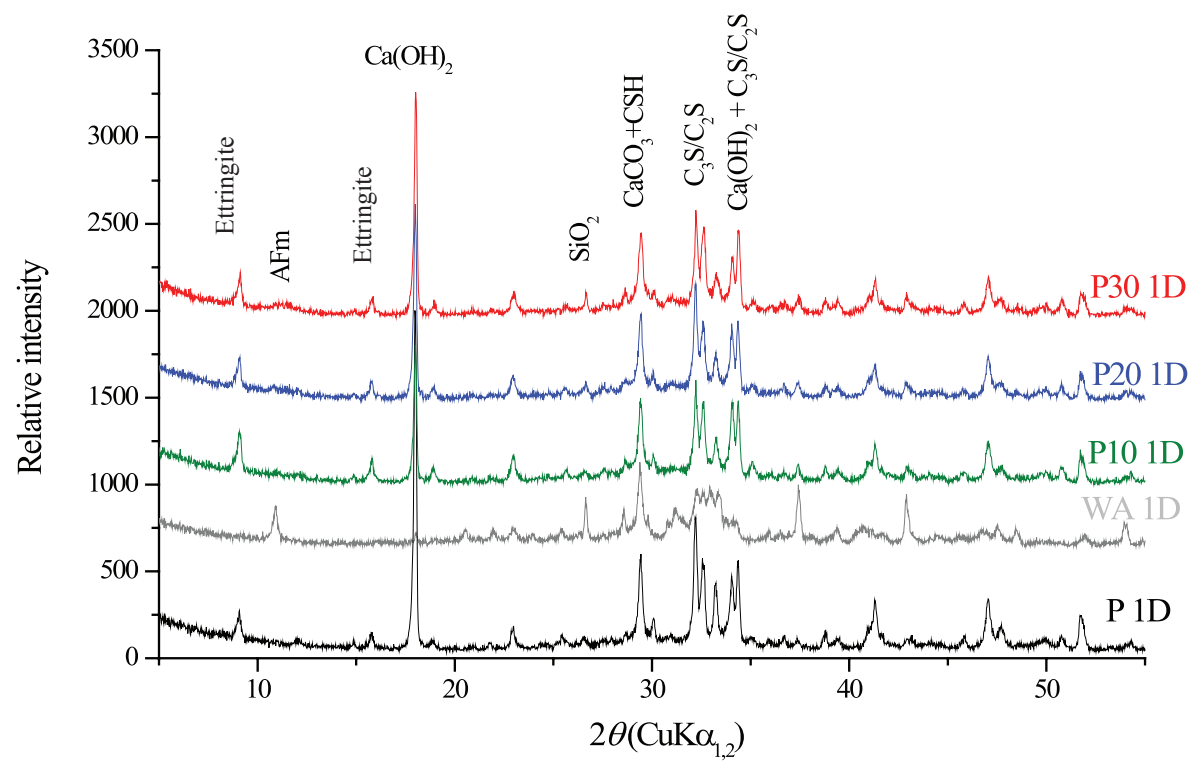

Fig. 7 - Powder X-ray diffraction analysis of cement paste $(w / c=0.5)$ hydrated for 1 day: Effect of woody ash addition (partially cement chemistry shorthand notation used: $\mathrm{C}-\mathrm{CaO}, \mathrm{S}-\mathrm{SiO}, \mathrm{H}-\mathrm{H}_{2} \mathrm{O}$ )

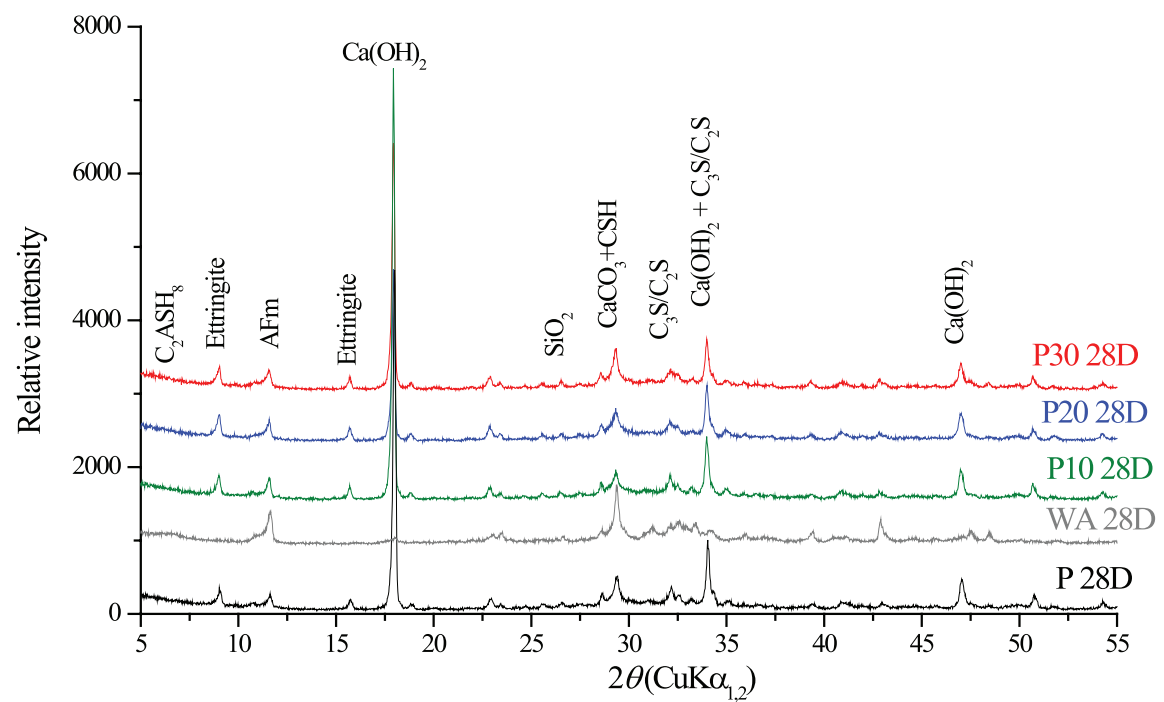

Fig. 8 - Powder X-ray diffraction analysis of cement paste $(w / c=0.5)$ hydrated for 28 days: Effect of fly ash addition (partially cement chemistry shorthand notation used: $\mathrm{C}-\mathrm{CaO}, \mathrm{S}-\mathrm{SiO}, \mathrm{A}-\mathrm{Al}_{2} \mathrm{O}_{3}, \mathrm{H}-\mathrm{H}_{2} \mathrm{O}$ )

\section{Mortar properties}

The results of fresh state mortar workability (by flow table test) with different replacement levels of cement and sand with ash are shown in the last row of Table 1. Specimens mixed with a constant water-to-cement ratio showed a decrease in workability with an increasing ash content (samples with 10, 15, and $20 \%$ cement replacement). This can be attributed to a coarser size distribution of ash than cement only (Fig. 1, $70 \%$ is higher than 80 $\mu \mathrm{m})$. When $15 \%$ of ash was added, but replacing 5 $\%$ of cement and $3.33 \%$ of sand (sample M5F15), the workability is exactly between values of $\mathrm{M}$ and
M10 samples. Superplasticizers may be used to control (avoid) the observed loss of workability with ash additions.

The effect of woody biomass ash incorporation on flexural (Fig. 9) and compressive strengths (Fig. 10) resulted in similar trends. With increasing cement replacement level the strength reduced. However, a $15 \%$ dosage of ash, replacing only $5 \%$ of cement, but $3.33 \%$ of the sand, still produced a good structural grade mortar (or concrete) with acceptable mechanical properties. The results (Fig. 10) also show that the compressive strength of all mixtures reduced when cured in a heated water bath at $100{ }^{\circ} \mathrm{C}$, except for the M20 mixture. 


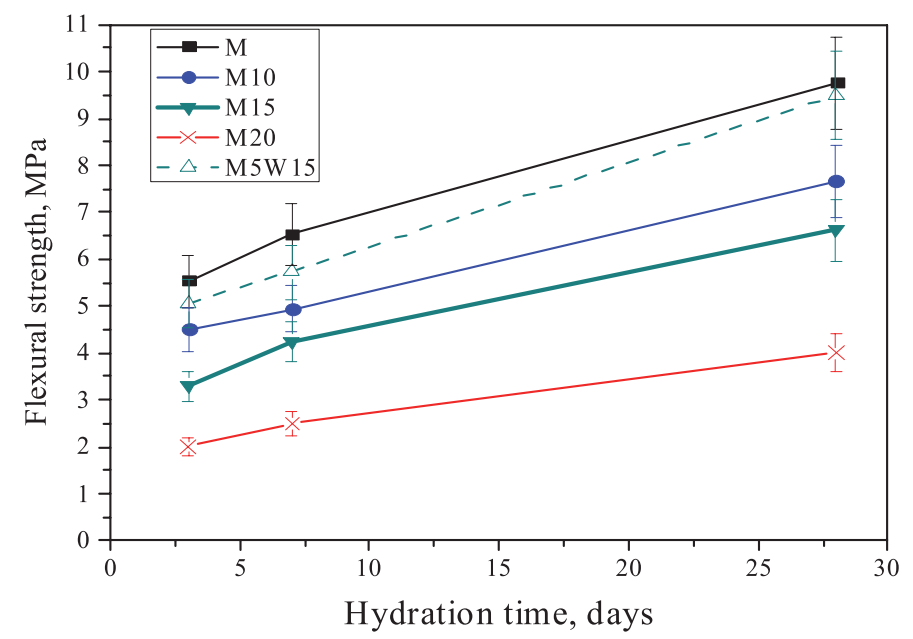

Fig. 9 - Development of compressive strength of mortar specimens: Effect of wood ash addition (mixture type Table 1) (error bars represent \pm two expected standard deviations)

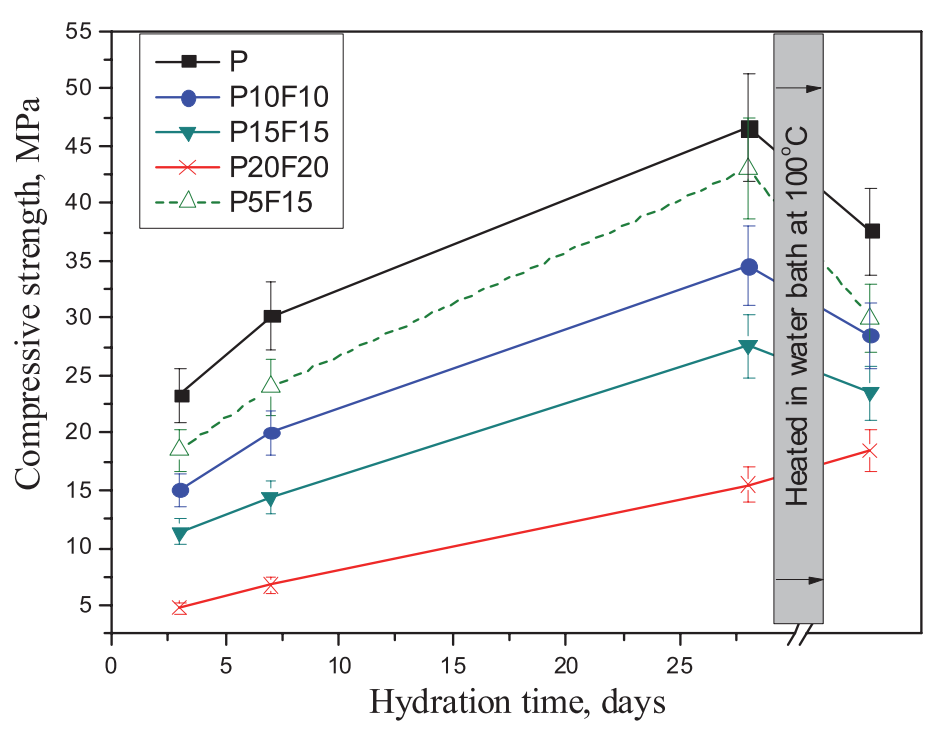

Fig. 10 - Development of compressive strength of mortar specimens: Effect of wood ash addition (mixture type Table 1) (error bars represent \pm two expected standard deviations)

\section{Conclusion}

Partial replacement of cement and sand in cementitious materials with $0-30 \%$ of coarse fly woody ash waste was investigated. Wood ash was characterized by chemical (XRF and other), mineralogical (XRD), and morphological (SEM, PSD and BET) analyses, followed by a hydration study of the paste samples (without sand) tested by calorimetry, XRD, TG, workability, and volume stability measurements. Lastly, mortar specimens (with standard sand) were tested for workability and mechanical properties. Based on the results, the following conclusions were drawn.

The chemical requirements for woody ash use in concrete according to EN 450-1 (year 2012) were not met due to coarse particle size distribution, an insufficient amount of pozzolanic oxides $\left(\mathrm{SiO}_{2}\right.$, $\mathrm{Al}_{2} \mathrm{O}_{3}$ and $\mathrm{Fe}_{2} \mathrm{O}_{3}$ ), and an excessive amount of alkalies, reactive $\mathrm{CaO}$ and $\mathrm{MgO}$. However, the ash was broadening the particle size distribution of cement as it comprised particles smaller than $1 \mu \mathrm{m}$ and larger than $100 \mu \mathrm{m}$. This showed the potential of woody ash to improve the packing density of blends, where both sand and cement were partially replaced by ash. Moreover, the presence of clinker minerals showed potential as a cement replacement material.

The addition of $20 \%$ ash resulted in unacceptable expansions, which increased rapidly with further ash dosage. This expansion was due to a delayed hydration of free and dead-burned $\mathrm{CaO}$ and $\mathrm{MgO}$. 
Plain ash hydration produced a maximal $\mathrm{Ca}(\mathrm{OH})$, quantity at 3 days and decreased with further hydration, demonstrating the pozzolanic activity of the ash. With increasing ash addition, more $\mathrm{Ca}(\mathrm{OH})_{2}$ was produced initially than for plain cement, due to hydraulic properties of the ash with a relatively high content of reactive $\mathrm{CaO}$, but at 28 days, inversely, there was less $\mathrm{Ca}(\mathrm{OH})_{2}$ due to activated pozzolanic reaction.

Hydration of ash alone showed a development of $3 \mathrm{CaO} \cdot \mathrm{Al}_{2} \mathrm{O}_{3} \cdot \mathrm{Ca}(\mathrm{OH})_{2} \cdot \mathrm{xH}_{2} \mathrm{O}$, stratlingite $\left(\mathrm{Ca}_{2} \mathrm{Al}_{2}\left(\mathrm{SiO}_{2}\right)\left(\mathrm{OH}_{10}\right)_{10} 2.5\left(\mathrm{H}_{2} \mathrm{O}\right)\right), \mathrm{CaCO}_{3}$ and/or calcium-silicate hydrates. The main effect of ash on hydration, visible by semi-quantitative XRD analysis, was in production of $3 \mathrm{CaO} \cdot \mathrm{Al}_{2} \mathrm{O}_{3} \cdot \mathrm{Ca}(\mathrm{OH})_{2}$. $\mathrm{xH}_{2} \mathrm{O}$ phase, which increased with ash addition.

With increase in the cement replacement level, the hydration kinetics, workability, compressive and flexural strength significantly reduced. However, the optimum dosage of $15 \%$ woody ash, replacing $5 \%$ of cement, but $3.33 \%$ of the sand, still produced a structural grade mortar (or concrete) with acceptable workability and mechanical properties. Thus, potential reuse of ash could reduce landfilling, and at the same time improve the sustainability perspective of cement production, reducing energy needs for cement production, cutting back in $\mathrm{CO}_{2}$ emissions, and preserving natural resources (i.e. limestone) with no concern for depletion of biomass ash supplies.

Future research should investigate the effect of washing (pre-hydration and carbonation) and mechanical (grinding) pre-treatments of the woody ash on blended cement properties (i.e. on expansion potential). The potential of woody ash as an expansive additive to mitigate autogenous shrinkage of cement-based materials represents a new research line worth investigating.

\section{ACKNOWLEDGEMENT}

The authors thank for assistance with the following measurements: a) XRF performed at TU Delft, b) SEM and part of TG performed with $d r$. Vilko Mandic, and c) unburned carbon test (EN15104) performed at Central Laboratory for Chemical Technology, part of HEP Proizvodnja d.o.o (Dr. Marija Trkmić). Credit is given also to Lika Eko-Energo d.o.o., Udbina, Croatia (Mr. Zeljko Lovrak) for discussions and kind supply of the woody ash samples.

\section{References}

1. Directive 2009/28/EC "Promotion of the use of energy from renewable resources".

2. Carrasco-Hurtado, B., Corpas-Iglesias, F. A., Cruz-Perez, N., Terrados-Cepeda, J., Perez-Villarejo, L., Addition of bottom ash from biomass in calcium silicate masonry units for use as construction material with thermal insulating properties, Constr. Build. Mater. 52 (2014) 155. doi: http://dx.doi.org/10.1016/j.conbuildmat.2013.11.018

3. Obernberger, I., Supancic, K., Possibilities of ash utilization from biomass combustion plants, in Proceedings of the 17th European Biomass Conference \& Exhibition, Hamburg, Germany, 2009.

4. Van Eijk, R. J., Obernberger, I., Supancic, K., Options for increased utilization of ash from biomass combustion and co-firing. IEA Bioenergy Task 32: Biomass combustion and co-firing. Arnhem, Netherlands 2012.

5. Doudart de la Grée, G. C. H., Florea, M. V. A., Keulen, A., Brouwers, H. J. H., Contaminated biomass fly ashes Characterization and treatment optimization for reuse as building materials, Waste Management 49 (2016) 96. doi: http://dx.doi.org/10.1016/j.wasman.2015.12.023

6. Berra, M., Mangialardi, T., Paolini, A. E., Reuse of woody biomass fly ash in cement-based materials, Constr. Build. Mater. 76 (2015) 286. doi: http://dx.doi.org/10.1016/j.conbuildmat.2014.11.052

7. Cheah, B. C., Ramli, M., The implementation of wood waste ash as a partial cement replacement material in the production of structural grade concrete and mortar: An overview, Resour. Conserv. Recycling 55 (2011) 669. doi: http://dx.doi.org/10.1016/j.resconrec.2011.02.002

8. Barbosa, R., Lapa, N., Dias, D., Mendes, B., Concretes containing biomass ashes: Mechanical, chemical, and ecotoxic performances, Constr. Build. Mater. 48 (2013) 457. doi: http://dx.doi.org/10.1016/j.conbuildmat.2013.07.031

9. Cheah, B. C., Ramil, M., The fluid transport properties of HCWA-DSF hybrid supplementary binder mortar, Composites: Part B 56 (2014) 681. doi: http://dx.doi.org/10.1016/j.compositesb.2013.09.021

10. Sierra Beltran, M. G., Ukrainczyk, N., Schlangen, E., 2014. Development of SHCC with biomass fly ash. In Schlangen E., Sierra Beltran, M. G., Lukovic, M., Ye, G. (Eds.), Proceedings of the 3rd international RILEM conference on strain hardening cementitious composites (SHCC3-Delft) Delft, TU Delft, Netherlands, 87-95.

11. Lothenbach, B., Scrivener, K., Hooton, R. D., Supplementary cementitious materials, Cem. Concr. Res. 41 (2011) 1244. doi: http://dx.doi.org/10.1016/j.cemconres.2010.12.001

12. Schneider, M., Romer, M., Tschudin, M., Bolio, H., Sustainable cement production - present and future, Cem. Concr. Res. 41 (2011) 642. doi: http://dx.doi.org/10.1016/j.cemconres.2011.03.019

13. CEMBUREAU, the European Cement Association report 2014, http://www.cembureau.be/about-cement/key-facts-figures

14. NEN 450-1: Fly ash in concrete, 2012.

15. Saraber, A. J., Feuerborn, H. J., Berg van den, J. W., 2009. Fly ash for concrete, CEN TC 104MIG 4 DOC 83-2009. Backgrounds to the revision of EN 450-1: 2005/A1:2007 and EN 450-2:2005.

16. Pöykiö, R., Rönkkömäki, H., Nurmesniemi, H., Perämäki, P., Popov, K., Välimäki, I., Tuomi, T., Chemical and physical properties of cyclone fly ash from the grate-fired boiler incinerating forest residues at a small municipal district heating plant (6 MW). J. Hazard. Mater. 162 (2009) 1059. doi: http://dx.doi.org/10.1016/j.jhazmat.2008.05.140

17. Ribbing, C. M., Bjurström, H. G., The Swedish ash programme with focus on bioashes: ashes are a resource in a sustainable society. Chap. 11 in: Insam, K., Knapp, B., (Eds.), Recycling of biomass ashes, Springer-Verlag, Berlin; 2011. p. 147-64. doi: http://dx.doi.org/10.1007/978-3-642-19354-5_11 
18. Oburger, E., Jäger, A., Pasch, A., Dellantonio, A., Stampfer, $K$., Wenzel, $W$. $W$., Environmental impact assessment of wood ash utilization in forest road construction and maintenance - A field study, Science of the Total Environment 544 (2016) 711.

doi: http://dx.doi.org/10.1016/j.scitotenv.2015.11.123

19. Rajamma, R., Labrincha, J. A., Ferreira, V. M., Alkali activation of biomass fly ash-metakaolin blends, Fuel 98 (2012) 265. doi: http://dx.doi.org/10.1016/j.fuel.2012.04.006

20. Lo, T. Y., Cui, H., Ali Memon, S., Noguchi, T., Manufacturing of sintered lightweight aggregate using high-carbon fly ash and its effect on the mechanical properties and microstructure of concrete, Journal of Cleaner Production 112 (2016) 753. doi: http://dx.doi.org/10.1016/j.jclepro.2015.07.001

21. Pérez-Villarejo, L., Eliche-Quesada, D., Iglesias-Godino, F. J., Martínez-García, C., Corpas-Iglesias, F. A., Recycling of ash from biomass incinerator in clay matrix to produce ceramic bricks, Journal of Environmental Management 95 (2012) S349. doi: http://dx.doi.org/10.1016/j.jenvman.2010.10.022

22. Oye, B., Wood ash as raw material for Portland cement, ASH Utilisation 2012, Stockholm, Sweden, January 25-27. (http://www.varmeforsk.se/files/program/askor/Bjarte_ye.pdf)

23. Hasanbeigi, A., Price, L., Lin, E., Emerging energy-efficiency and $\mathrm{CO} 2$ emission-reduction technologies for cement and concrete production: A technical review, Renewable and Sustainable Energy Reviews 16 (2012) 6220. doi: http://dx.doi.org/10.1016/j.rser.2012.07.019

24. Chowdhury, S., Mishra, M., Suganya, O., The incorporation of wood waste ash as a partial cement replacement material for making structural grade concrete: An overview, Ain Shams Engineering Journal 6 (2015) 429. doi: http://dx.doi.org/10.1016/j.asej.2014.11.005
25. Rajamma, R., Senff. L., Ribeiro, M. J., Labrincha, J. A., Ball, R. J., Allen, G. C., Ferreira, V. M., Biomass fly ash effect on fresh and hardened state properties of cement based materials, Compos. Part B Eng. 77 (2015) 1. doi: http://dx.doi.org/10.1016/j.compositesb.2015.03.019

26. Croatian Energy Strategy (in Croatia), Strategija energetskog razvoja Republike Hrvatske, Narodne Novine 130/09, 2009.

27. Ukrainczyk, N., Sabo, S., Laboratory made differential calorimeter to study cement hydration, Proc. of int. conf. on materials, tribology, recycling (MATRIB 2011), Schauperl, Z., Šolić, S., (Eds.), Vela Luka 2011, HDMT, Zagreb, 2011, 515-527.

28. Chaussadent, T., Arliguie, G., AFREM test procedures concerning chlorides in concrete: Extraction and titration methods, Mater. Struct. 32 (1999) 230. doi: http://dx.doi.org/10.1007/BF02481520

29. Ukrainczyk, N., Chemical Shrinkage During Hydration Reactions of Calcium Aluminate Cement, Austin J. Chem. Eng. 1 (2014) 1.

30. Polat, R., Demirboga, R., Khushefati, W. H., Effects of nano and micro size of $\mathrm{CaO}$ and $\mathrm{MgO}$, nano-clay and expanded perlite aggregate on the autogenous shrinkage of mortar, Constr. Build. Mater. 81 (2015) 268. doi: http://dx.doi.org/10.1016/j.conbuildmat.2015.02.032

31. Marsh, B. K., Day, R. L., Pozzolanic and cementitious reactions of fly ash in blended cement pastes, Cem. Concr. Res. 18 (1988) 301. doi: http://dx.doi.org/10.1016/0008-8846(88)90014-2

32. Gosselin, C., Gallucci, E., Scrivener, K., Influence of self heating and $\mathrm{Li}_{2} \mathrm{SO}_{4}$ addition on the microstructural development of calcium aluminate cement, Cem. Concr. Res. 40 (2010) 1555. doi: http://dx.doi.org/10.1016/j.cemconres.2010.06.012 